THE END OF IMPERIAL RUSSIA, 1855-1917 


\section{European History in Perspective General Editor: Jeremy Black}

Benjamin Arnold Medieval Germany

Ronald Asch The Thirty Years' War

Nigel Aston The French Revolution, 1789-1804

Nicholas Atkin The Fifth French Republic

Christopher Bartlett Peace, War and the European Powers, 1814-1914

Robert Bireley The Refashioning of Catholicism, 1450-1700

Donna Bohanan Crown and Nobility in Early Modern France

Arden Bucholz Moltke and the German Wars, 1864-1871

Patricia Clavin The Great Depression, 1929-1939

Paula Sutter Fichtner The Habsburg Monarchy, 1490-1848

Mark R. Forster Catholic Germany from the Reformation to the Enlightenment

Mark Galeotti Gorbachev and his Revolution

David Gates Warfare in the Nineteenth Century

Alexander Grab Napoleon and the Transformation of Europe

Martin P. Johnson The Dreyfus Affair

Tim Kirk Nazi Germany

Ronald Kowalski European Communism

Paul Douglas Lockhart Sweden in the Seventeenth Century

Kevin McDermott Stalin

Graeme Murdock Beyond Calvin

Peter Musgrave The Early Modern European Economy

J. L. Price The Dutch Republic in the Seventeenth Century

A. W. Purdue The Second World War

Christopher Read The Making and Breaking of the Soviet System

Francisco J. Romero-Salvado Twentieth-Century Spain

Matthew S. Seligmann and Roderick R. McLean

Germany from Reich to Republic, 1871-1918

David A. Shafer The Paris Commune

David Sturdy Louis XIV

David J. Sturdy Richelieu and Mazarin

Hunt Tooley The Western Front

Peter Waldron The End of Imperial Russia, 1855-1917

Peter Waldron Governing Tsarist Russia

Peter G. Wallace The Long European Reformation

James D. White Lenin

Patrick Williams Philip /I

Peter $\mathrm{H}$. Wilson From Reich to Revolution

European History in Perspective
Series Standing Order
ISBN 978-0-333-71694-6 hardcover
ISBN 978-0-333-69336-0 paperback
(outside North America only)

You can receive future titles in this series as they are published by placing a standing order. Please contact your bookseller or, in the case of difficulty, write to us at the address below with your name and address, the title of the series and the ISBN quoted above. 


\title{
THE END OF IMPERIAL RUSSIA, 1855-1917
}

\section{Peter Waldron}

\author{
Reader in History \\ University of Sunderland
}

palgrave
macmillan 


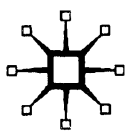

All rights reserved. No reproduction, copy or transmission of this publication may be made without written permission.

No paragraph of this publication may be reproduced, copied or transmitted save with written permission or in accordance with the provisions of the Copyright, Designs and Patents Act 1988, or under the terms of any licence permitting limited copying issued by the Copyright Licensing Agency, 90 Tottenham Court Road, London W1T 4LP.

Any person who does any unauthorised act in relation to this publication may be liable to criminal prosecution and civil claims for damages.

The author has asserted his right to be identified as the author of this work in accordance with the Copyright, Designs and Patents Act 1988.

Published by PALGRAVE MACMILLAN

Houndmills, Basingstoke, Hampshire RG21 6XS and

175 Fifth Avenue, New York, N. Y. 10010

Companies and representatives throughout the world

PALGRAVE MACMILLAN is the global academic imprint of the Palgrave Macmillan division of St. Martin's Press, LLC and of Palgrave Macmillan Ltd. Macmillan ${ }^{\oplus}$ is a registered trademark in the United States, United Kingdom and other countries. Palgrave is a registered trademark in the European Union and other countries.

Outside North America

ISBN 978-0-333-60168-6 ISBN 978-1-349-25483-5 (eBook)

DOI 10.1007/978-1-349-25483-5

In North America

ISBN 978-0-312-16536-9 hardcover ISBN 978-0-312-16537-6 paperback

This book is printed on paper suitable for recycling and made from fully managed and sustained forest sources. Logging, pulping and manufacturing processes are expected to conform to the environmental regulations of the country of origin.

A catalogue record for this book is available from the British Library.

A catalogue record for this book is available from the Library of Congress

Transferred to digital printing 2002 


\section{Contents}

Preface

vi

Note on Names and Dates

viii

1 The Politics of Autocracy

2 Field and Factory: The Russian Economy

3 The Transformation of Russian Society

4 Empire and Europe

103

5 The End of the Old Order

Notes

165

Select Bibliography

176

Index

186 


\section{PREFACE}

The disintegration of the Soviet Union, and the attendant downfall of the political system which had been created when Lenin and the Bolsheviks took power in October 1917, has engendered renewed interest in Tsarist Russia. Russians themselves have become able to examine the history of their own country with greater equanimity than was possible under the Soviet regime. The last decades of Tsarism have become the subject of considerable attention as contemporary Russia seeks to understand the circumstances which enabled the Bolsheviks to come to power.

The experience of imperial Russia also has a wider significance. Between 1855 and 1917 Russia changed dramatically. Modernization - political, economic and social - gripped the state as the old order tried to come to grips with a Europe-wide process of change stimulated by the twin cataclysms of political revolution in France in 1789 and of industrial revolution that left almost no part of the continent untouched. The Tsarist regime tried to maintain a difficult balancing act, torn between the desire to preserve its own authority intact and the need to cope with the stresses brought by rapid economic and social change. This was not a situation unique to nineteenth-century Russia: other contemporary regimes faced the same problems, while the twentieth century has witnessed numerous examples of the impact of economic modernization on political and social structures.

This book seeks to illuminate the chief issues that faced the people of the Russian Empire between 1855 and 1917. A huge, multinational state, playing a major role on the 
international stage, Russia was beset by all manner of challenges. By adopting a largely thematic approach, I have tried to draw attention to the continuities in the history of imperial Russia and to show the interplay of political, economic, social and international forces.

Since 1917, historians have debated many aspects of the history of imperial Russia and the origins of the Russian revolution at length and with great skill. Each generation of historians has sought to bring its own perspectives to bear on the problems of imperial Russia. History, however, is not made by historians but by the people of the past and it is their experience - whether peasant or Tsar, Moscow worker or Siberian colonist - that is of central concern to us. I have avoided direct reference to debates between historians: the bibliography provides pointers to enable the reader to get to grips with this dimension of the topic.

Writing a book of this type means drawing widely on the writings of others. I have tried to indicate my most significant sources in the notes and the bibliography, but must beg indulgence of colleagues whose contributions to my ideas I have failed to acknowledge. I am extremely grateful to Don MacRaild and Mike Rapport for reading the manuscript and offering many suggestions that have much improved it. Clare Crowley's comments on the text have been of very great value, as has been her support over the years.

Peter Waldron 


\section{Note On NAMES AND DATES}

Russian names are always difficult to deal with: I have used the familiar English version of the names of Tsars etc., but have left other names in their Russian form. Until February 1918, Russia operated the Julian calendar. In the nineteenth century, dates were 12 days behind the West and after 1900, 13 days behind. I have used the Russian calendar throughout and have added the Western equivalent where necessary in dealing with international affairs. 